\title{
Polyphase deformation in a newly emerged accretionary prism: Folding, faulting and rotation in the southern Taiwan mountain range
}

\author{
Chung-Pai Chang ${ }^{\mathrm{a}, \mathrm{b}, *}$, Jacques Angelier ${ }^{\mathrm{c}}$, Chia-Yu Lu ${ }^{\mathrm{d}}$ \\ ${ }^{\text {a }}$ Center for Space and Remote Sensing Research, National Central University, Chungli, Taiwan \\ ${ }^{\mathrm{b}}$ Department of Earth Sciences and Institute of Geophysics, National Central University, Chungli, Taiwan \\ c Observatoire Océanologique de Villefrance-Géosciences Azur, Université Pierre-et-Marie-Curie, Villefrance/Mer, France \\ ${ }^{\mathrm{d}}$ Department of Geosciences, National Taiwan University, Taipei, Taiwan
}

Available online 17 November 2007

\begin{abstract}
In Taiwan, the oblique late Cenozoic collision of the Eurasian Plate with the Luzon arc provides an opportunity to observe the development of arc-continent collision. However, analyses of tectonic structures demonstrate that a simple ESE-WNW compression, as induced by the arccontinent collision, fails to explain all aspects of the Taiwan Mountain building processes. This is the case for the rapid uplift and exhumation of the metamorphic rocks, the east-west trending fold-and-thrust systems in southeastern Taiwan, the tectonic rotation of the Hengchun peninsula, the escape phenomenon in the Ilan and Pingtung Plains, which are difficult to interpret using a "simple collision mechanism". In this paper we focus on the structural record of southern Taiwan mountain range, in order to clarify the process of deformation in the growing accretionary prism. In view of geological stratigraphy, the southern Taiwan is underlain by thick series of Miocene deposits, including dark gray argillites, flysch deposits with occasional interbeds of gray compact sandstone and disseminated marly nodules. Field works have been done to reconstruct the main tectonic paleostress and deformation events of this region. Polyphase brittle and fold structures are largely distributed in this area, which allows us to determine the tectonic history in terms of nature, direction, importance and relative chronology of the main deformation events of the Late Cenozoic. These results provide an important key to reconstruct the in situ geotectonic history of the southern Taiwan region, which can be discussed in terms of four main stages. The stage 0 corresponds to the Early to Middle Miocene time, with WNW-ESE extension. The stage I corresponds to the Late Miocene to Pliocene time, when the study area were incorporated into the accretionary prism by west-verging thrust faults. The stage II is Pliocene in age, with continuing compression between the volcanic arc and the continental margin producing series of east-verging backthrusts. During the Plio-Pleistocene time, arc-continent collision occurred in Taiwan, as stage III in our study area, which produced conspicuous transpressional structures in the southern Central Range. A new mountain building model, involving limited counterclockwise rotation in the transition zone between incipient collision and mature collision, is also proposed to explain the recent deformation mechanism of the southern Taiwan range.
\end{abstract}

(C) 2007 Elsevier B.V. All rights reserved.

Keywords: Polyphase deformation; Accretionary prism; Southern Taiwan

\section{Introduction}

The Taiwan mountain belt, located at the boundary between the Philippine Sea plate and the Eurasian Plate, is a product of arc-continent collision (Chai, 1972; Biq, 1973; Bowin et al., 1978 ) and is one of the most active and youngest mountain belts on the Earth (Fig. 1). The convergent velocity between the

\footnotetext{
* Corresponding author. Center for Space and Remote Sensing Research, National Central University, Jungli 320, Taoyuan, Taiwan.

E-mail address: cpchang@csrsr.ncu.edu.tw (C.-P. Chang).
}

Northern Luzon Arc and the Chinese continental margin has been estimated as $8.2 \mathrm{~cm} / \mathrm{yr}$ in the $\mathrm{N} 54^{\circ} \mathrm{W}$ direction (Yu et al., 1997), the original trend of the Northern Luzon Arc is $\mathrm{N} 10^{\circ} \mathrm{W}$ and the Chinese continental margin trends about $\mathrm{N} 60^{\circ} \mathrm{E}$. Because of this oblique geometry, the arc-continental collision and the mountain belt of Taiwan propagate southward (Suppe, 1984). This provides a good opportunity for Earth Scientists to study the structural evolution by moving from north to south along the Taiwan mountain belt.

As a newly emerged accretionary prism, the southernmost Central Range provides exceptional opportunity to study the 


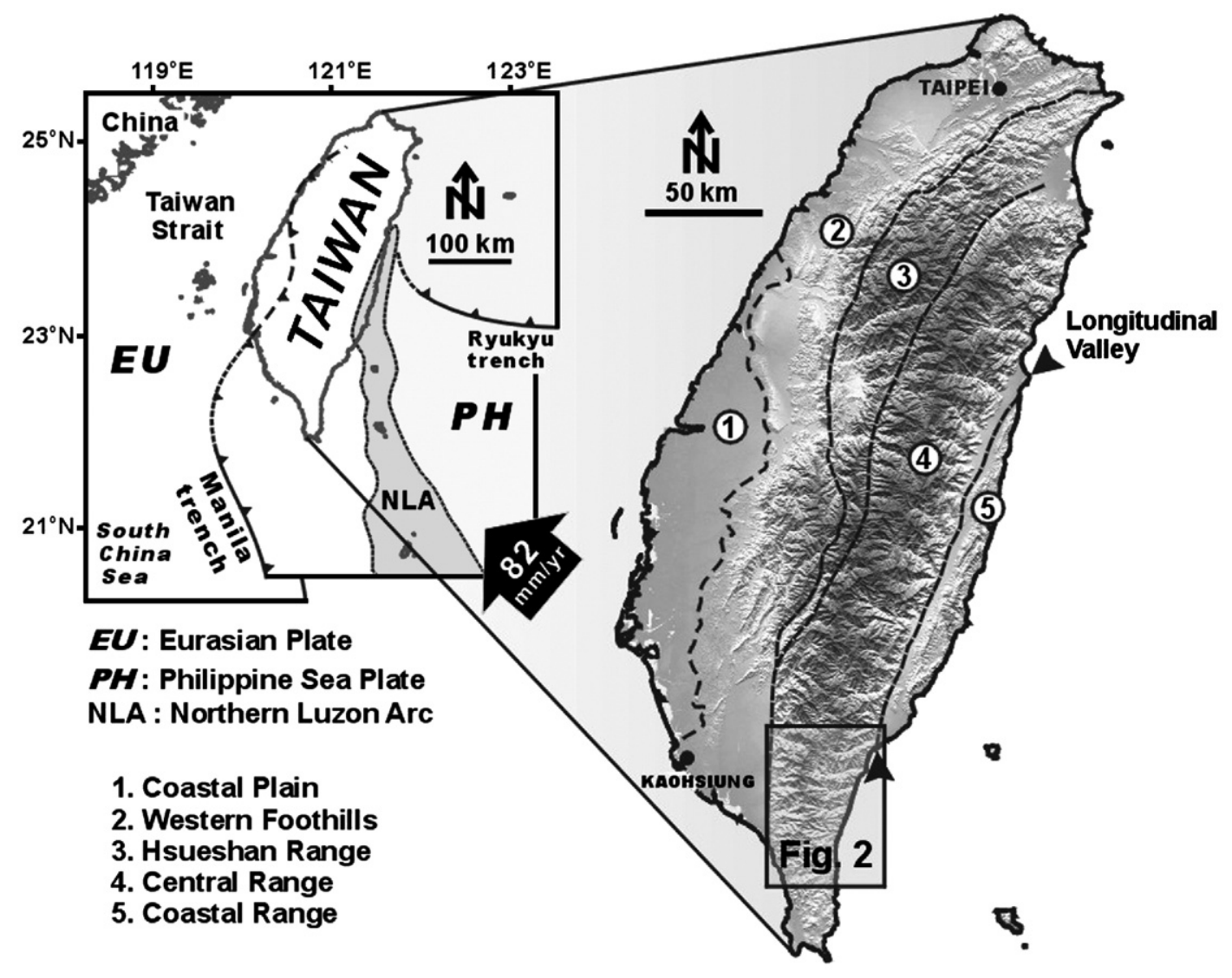

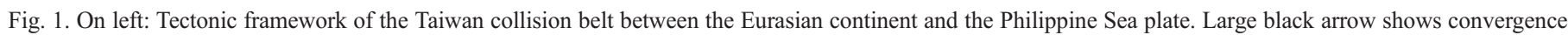

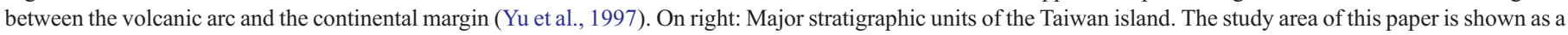
small rectangular frame (Fig. 2).

early history of the Taiwan orogeny. In this paper, we take advantage of this situation to carry out detailed field study in the emerged area. We mainly focus on the polyphase folding and faulting of this area, in order to clarify the structural evolution in the oblique growing mountain belt. Moreover, through a systematic back-tilting restoration, the original orientations of paleostress could be recognised. Except for the dominant E-W trending compressional stress related to the direction of arccontinental collision, the $\mathrm{N}-\mathrm{S}$ trending transpressional stress is also largely distributed in this area, which is an important key to reconstruct in situ the geotectonic history. We finally propose a new mountain building model to explain the recent deformation mechanism in the southern Taiwan Island.

\section{General geological setting}

The Taiwan island consists of five morphotectonic units, which are from west to east the Coastal Plain, Western Foothills, Hsüeshan Range, Central Range and Coastal Range (Fig. 1). From the tectonic point of view, the former four units belong to the emerged accretionary prism; the latter unit belongs to the collided volcanic arc; between these two groups, the Longitudinal Valley is the most obvious onshore plate boundary between the Eurasian plate and the Philippine Sea plate (Tsai, 1986; Ho, 1986). West of this boundary, the general morphology of the NNE-SSW trending Central Range gradually descends and anticlockwise rotates southward. Further south, this range thus trends N-S instead of NNE-SSW, especially in the Hengchun peninsula south of Fongkang (Fig. 2), and submerges as the Hengchun Ridge at about $21^{\circ} 21^{\prime}$. This segment can be regarded as the proto-Taiwan accretionary prism.

Before presenting our tectonic investigation, the stratigraphy of the southern Central Range deserves examination (Fig. 2). The Late Miocene turbidite sequences, as the so-called Mutan Formation, crop out in the southernmost portion of this range (Sung, 1991; Chang et al., 2003). The Mutan Formations is composed of alternated sandstones and shales, with numerous lenticular bodies of sandstone and conglomerates at variety of scales. These lenticular bodies represent typical deposits of submarine channels or canyons and deep sea fans from the continental slope to the base of the slope (Pelletier and Stephan, 1986; Sung, 1991). Sedimentological analyses of pebbles and lithic fragments revealed low-grade metamorphism, suggesting that the Mutan Formation may be derived from the rifted Asian continent margin to the northwest (Page and Lan, 1983). Until now, no evidence has been found to support that sediments came from the Taiwan mountain belt; it is thus reasonable to believe that this formation is pre-tectonic.

North of the Hengchun peninsula, the southern Central Range shows large outcrops of thick series of Miocene to Pliocene accretionary wedge deposits. These deposits contribute the 


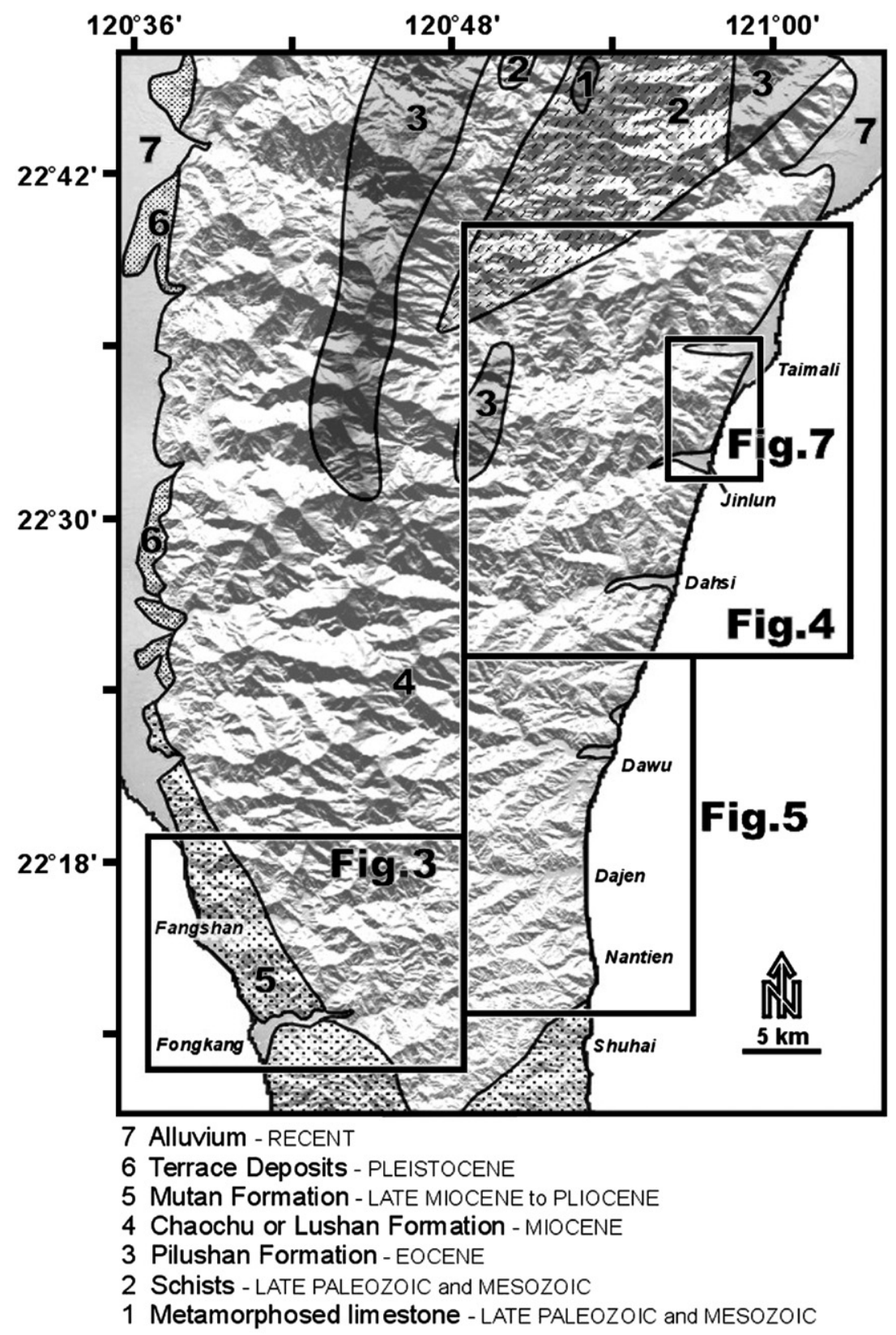

Fig. 2. General geological map of the southern Central Range (original data after Central Geological Survey). Location of Figs. 3, 4, 5, 7 are indicated. Main stratigraphic formations indicated. Topography clearly shows the well-aligned en-échelon structure pattern in the eastern flank of the Central Range.

Chaochu and Lushan Formations, including dark gray argillites, and flysch deposits with occasional interbeds of gray compact sandstone and disseminated marly nodules (Hu et al., 1981). These strata were metamorphosed under the prehnite-pumpellyite to lower greenschist facies during the Taiwan mountain building processes (Chen et al., 1983); they exhibit intense layer parallel shearing with or without slaty cleavage (Pelletier and $\mathrm{Hu}, 1984)$. Because at this latitude the Northern Luzon arc is still located at a large distance east of our study area, these strata have probably been exposed and exhumed before the mature arccontinental collision (Fig. 1). To the north, the metamorphic rocks, including the Eocene metasandstone and the Mesozoic schist and marble, are distributed in elongated, belt parallel zones. Because the high-grade metamorphic formations occupy a limited area and do not play an important role in reconstructing the regional tectonic history since the late Miocene time, they will not be discussed in this paper.

From the point of view of stratigraphy, the main formations of the southern Central Range are composed of metasediments that belonged to a very thick deep sea fan sequence. The clastic material was transported and deposited in the continental slope and ocean basin by turbidity currents (Hu and Tsan, 1984). On the other hand, the structural geology records seem complex (Fisher et al., 2002), giving rise to apparently contradictory observations. In this paper, we show that this complexity results from polyphase evolution, not from chaotic structure. For instance, the topography of the study area shows an intriguing pattern of ENE trending en-échelon ridges and valleys (Fig. 2), 
which in fact is related to large regional structures (faults and folds). This topographic pattern and structures are unusual in southern Taiwan, where most major structures trend approximately $\mathrm{N}-\mathrm{S}$. The presence of such contrasting structural grains reveals a polyphase tectonic history of folding and faulting.

\section{Monophase and polyphase structures}

The general structural geological map and profiles of the western flank of the southern Central Range are shown in Fig. 3. As could be expected on the west flank of the Taiwan belt, most faults and folds are west-verging. This $\mathrm{N}-\mathrm{S}$ trending structural
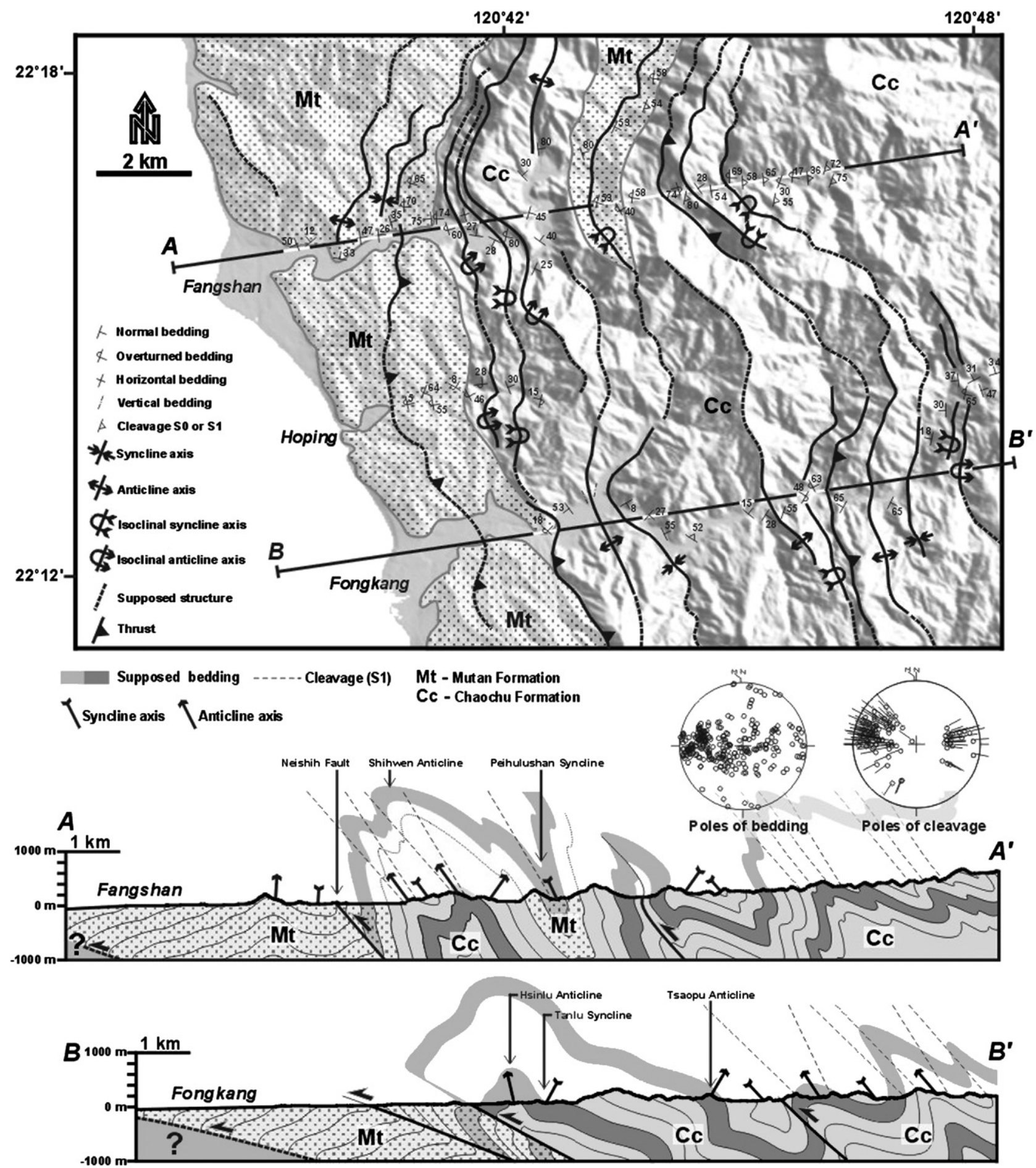

Fig. 3. General geological map and cross-sections of the eastern flank of the western Central Range. The N-S trending structural pattern suggests that most of the deformation resulted from an E-W directed compressional tectonic regime during the period of tectonic uplift. Stereoplots involve lower hemisphere, equal area projection. Location in Fig. 2. Fault slip data analysis in Fig. 10. 
pattern of this area suggests that most of the deformation result from an $\mathrm{E}-\mathrm{W}$ directed compressional tectonic regime during the period of tectonic uplift, which we name deformation Phase 1 hereafter. However, some structural evidences of polyphase tectonism are present, such as the eastern verging backthrusts, the western dipping cleavages and the E-W striking strata (the
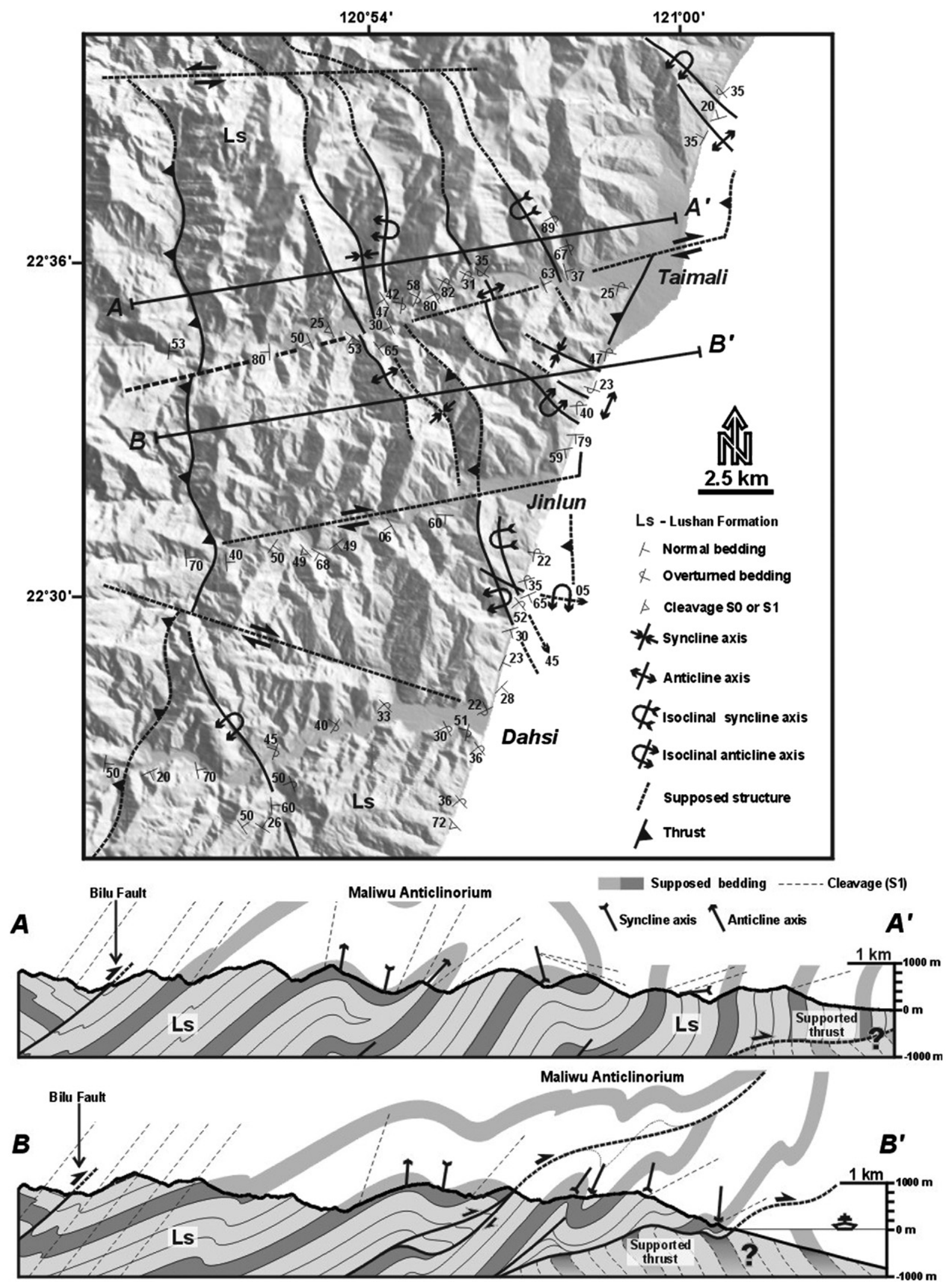

Fig. 4. General geological map and cross-sections of the eastern flank of the southern Central Range. Location in Fig. 2. Fault slip data analysis in Fig. 10. 


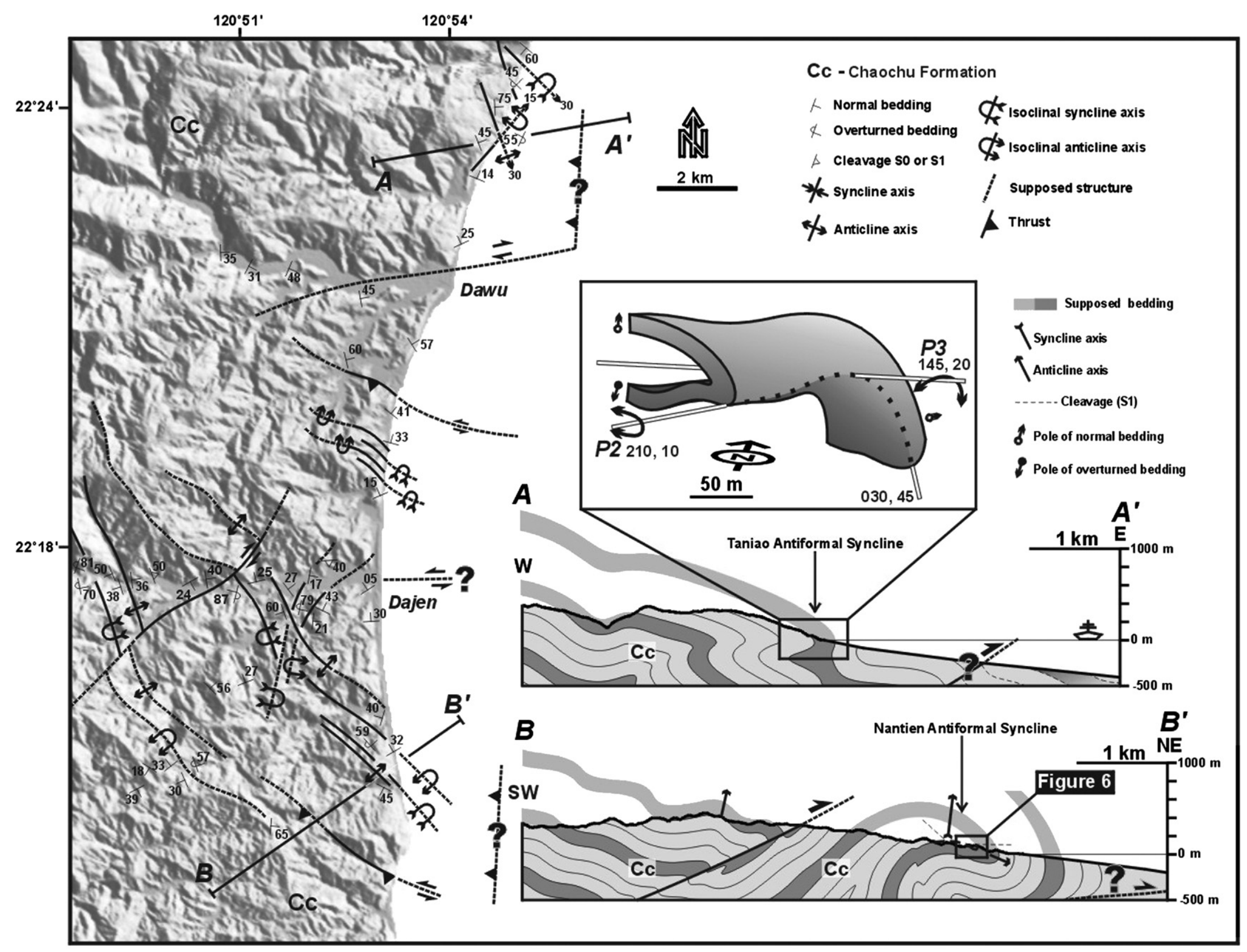

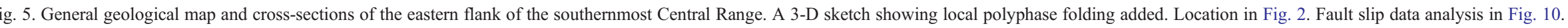


latter two being detectable in Fig. 3). We infer that the presentday structure of the western flank Central Range may result from a succession of tectonic events with various types and orientations of tectonic regimes. To decipher this structural evolution, we carried out detailed structural investigation in both flanks of the southern Central Range.

Two structural geological maps and some structural profiles of the eastern flank of the southern Central Range are shown in
Figs. 4 and 5. As mentioned in the previous section, the strata in the eastern flank of the southern Central Range were metamorphosed under the prehnite-pumpellyite to lower greenschist facies. The primary (sedimentary) structures in strata are thus difficult to identify. However, according the relationships between bedding and cleavage, which help delineating the major fold pattern, we found that overturned fold flanks are more common in this eastern side of the range than to the west. These

(a)

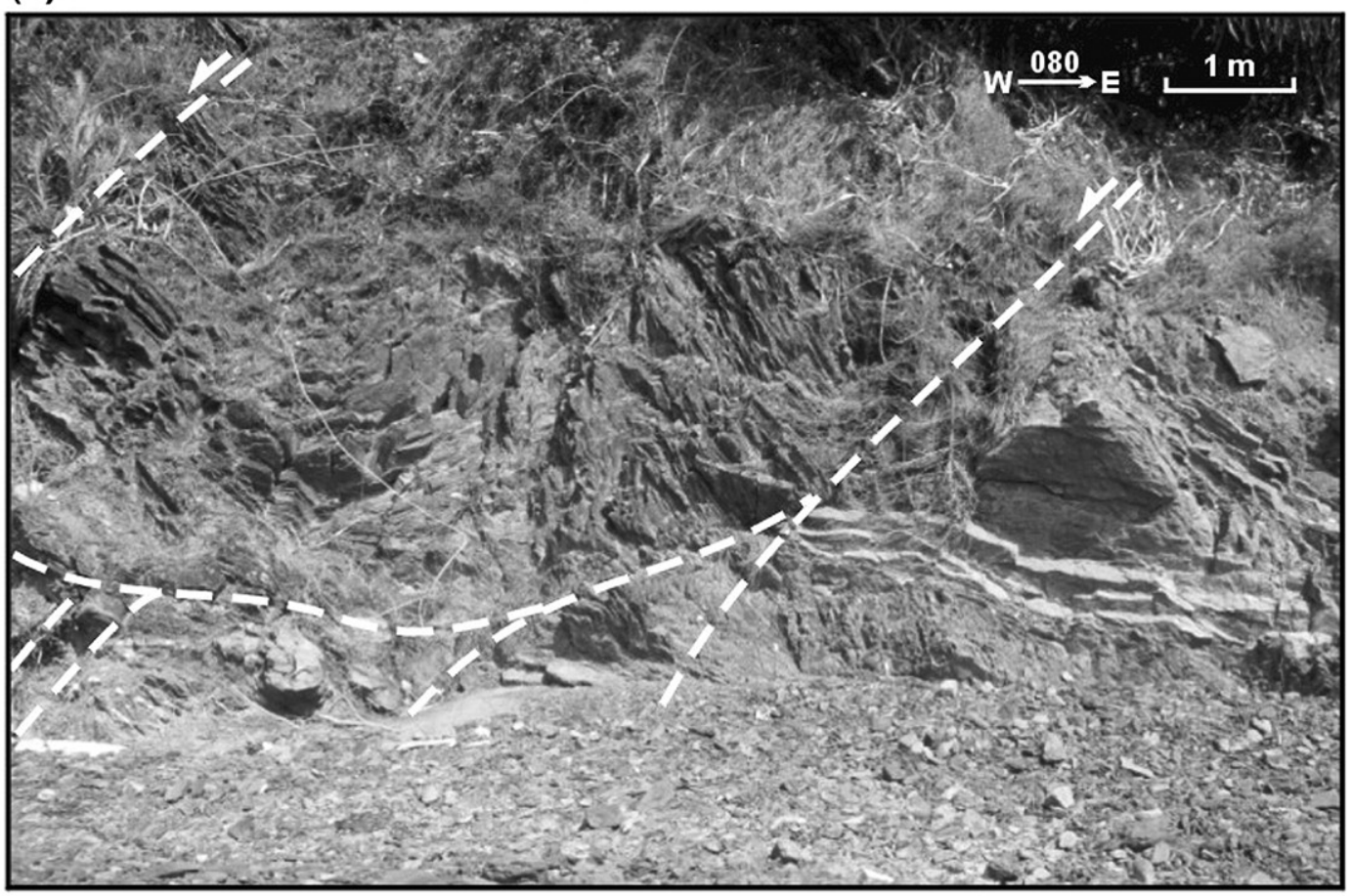

(b)

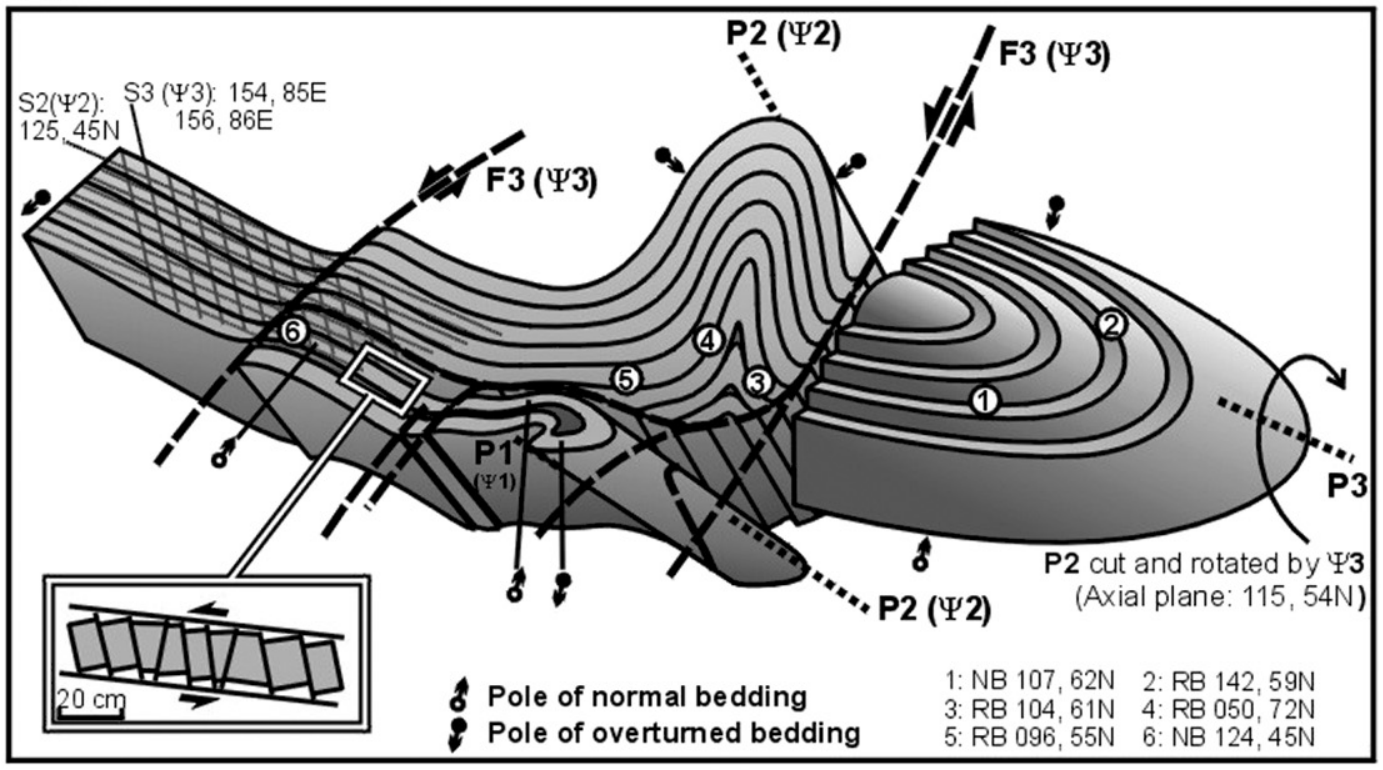

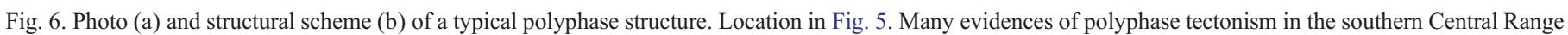
indicate that the present-day regional structure results from such succession of tectonic events $(1,2,3)$ with various types and orientations of tectonic regimes. 
overturned flanks are controlled by series of east-verging thrusts and major folds (Figs. 4 and 5). This fold pattern indicates that during the Taiwan mountain building processes this area underwent particular backthrusting deformation (Phase 2), contrasting with the general west-verging thrusting regime in Taiwan (Phase 1). We name this backthrusting deformation Phase 2, knowing however that it result from the same E-W directed compression and may have occurred simultaneously with respect to west-verging thrusting. This Phase 2 should thus be considered as an advanced stage of Phase 1 .

In more detail, a scheme of a complex fold at the outcrop scale is shown in profile AA' of Fig. 5. The fold axis formed by the backthrust (P2, fold of Phase 2) is deflected by another fold (P3, fold of Phase 3). The axis of the later fold is almost perpendicular to the former one (Fig. 5). Such observations led us to consider another phase of deformation, named Phase 3, in this region. The corresponding tectonic regime is quite different with respect to the former two regimes, with an approximately $\mathrm{S}-\mathrm{N}$ directed compression. In Fig. 6, showing another small outcrop, the relationship between the three phases of deformation is illustrated. The folds and faults that result from the first and second phases (P1 and P2) have similar trends, the first folds being affected by the second ones (see P1-P2 near the center of figure). The fold of the third phase (P3) developed in a different direction and indicated tilting of the older two folds (Fig. 6). Such observations showed that Phases 1 and 2 resulted from an $\mathrm{E}-\mathrm{W}$ directed compression (with Phase 1 dominated by west-verging thrusts and Phase 2 corresponding to east-verging backthrusts), whereas Phase 3 resulted from a S-N directed compression. To avoid confusion in the following text and figures, we use symbols $\Psi 0, \Psi 1, \Psi 2$, and $\Psi 3$ to represent the deformation of Phases 0 (principally expressed by synsedimetary structures), 1, 2, and 3 respectively.

The structures exhibited along the $\mathrm{N}-\mathrm{S}$ trending Taimali beach (location in Fig. 2) provide a spectacular illustration of the role of $\Psi 3$, through an interpreted structural section shown in Fig. 7. Measured bedding and cleavages along this beach are also shown in figure (as stereoplots). Two representative outcrops in this beach are shown in Fig. 8. We observed series of $\mathrm{E}-\mathrm{W}$ trending fold structures and clear indication of overturned strata, showing that the two antiforms in Fig. 8 are not anticlines but synclines (that is, antiformal synclines, a rather uncommon feature). This surprising structural pattern can be interpreted with reference to the regional structure: the profile BB' of Fig. 4 shows that the rock formations along this beach belong to the overturned flank of a large isoclinal anticline with a $\mathrm{N}-\mathrm{S}$ trending axis, which probably formed during $\Psi 2$. Because the structures affecting this major overturned flank, and postdating $\Psi 2$, generally trend $\mathrm{E}-\mathrm{W}$, it is reasonable to infer that an approximately $\mathrm{N}-\mathrm{S}$ directed compression has controlled the regional deformation during $\Psi 3$.

Other particular features, such as cleavage distributions, have been discussed in a previous paper (Lu et al., 2001). To better investigate the succession of tectonic regimes, especially

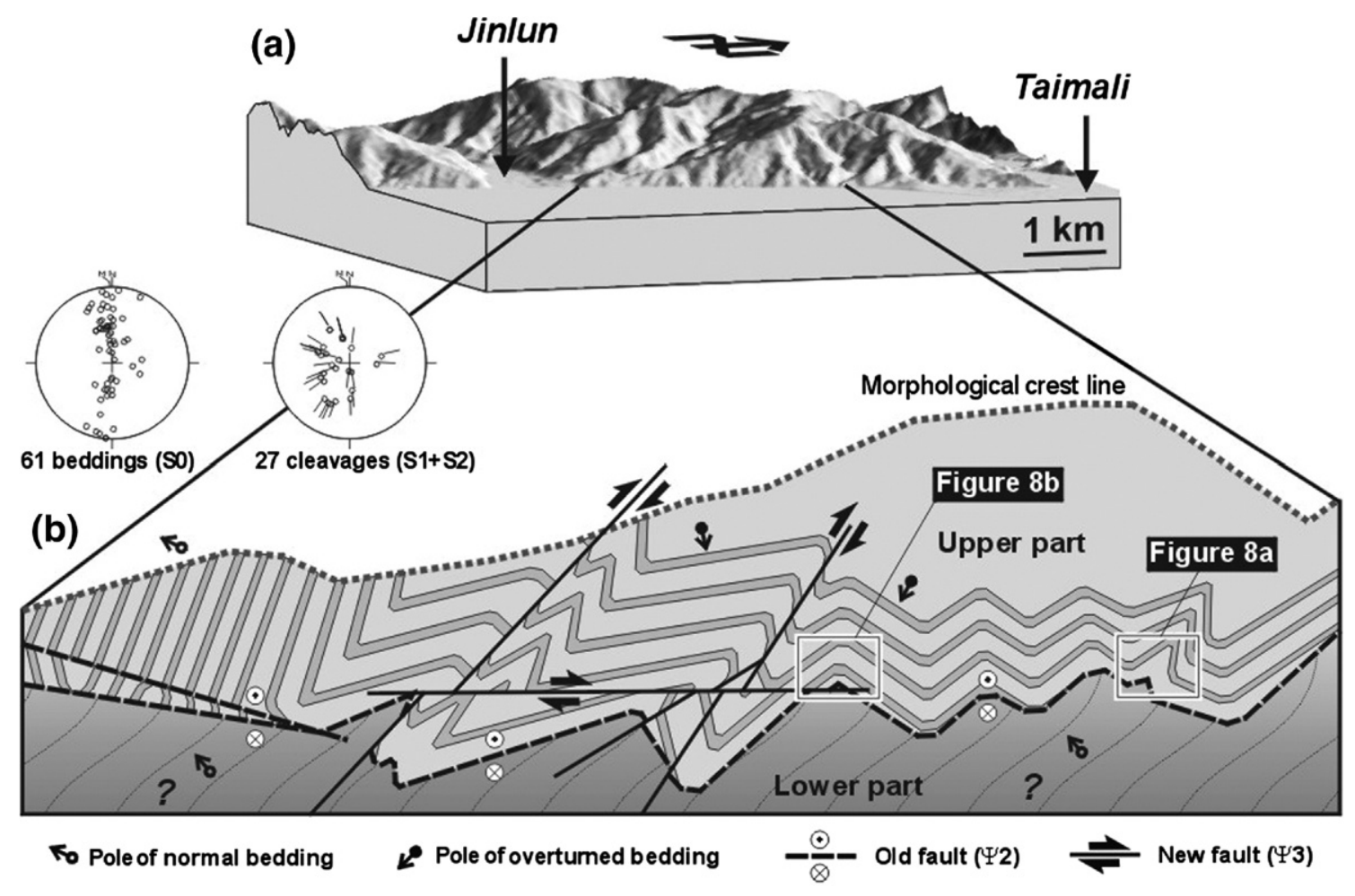

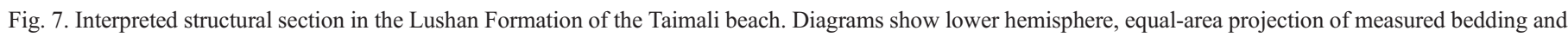

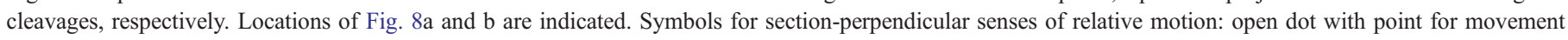
towards observer; open dot with cross for movement away from observer. 
(a)
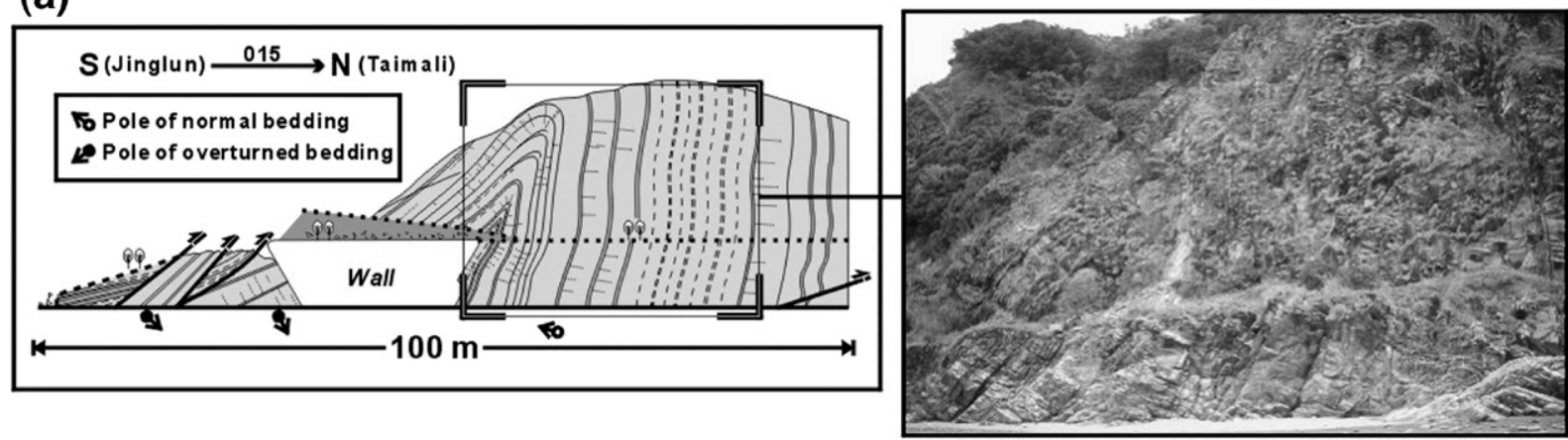

(b)

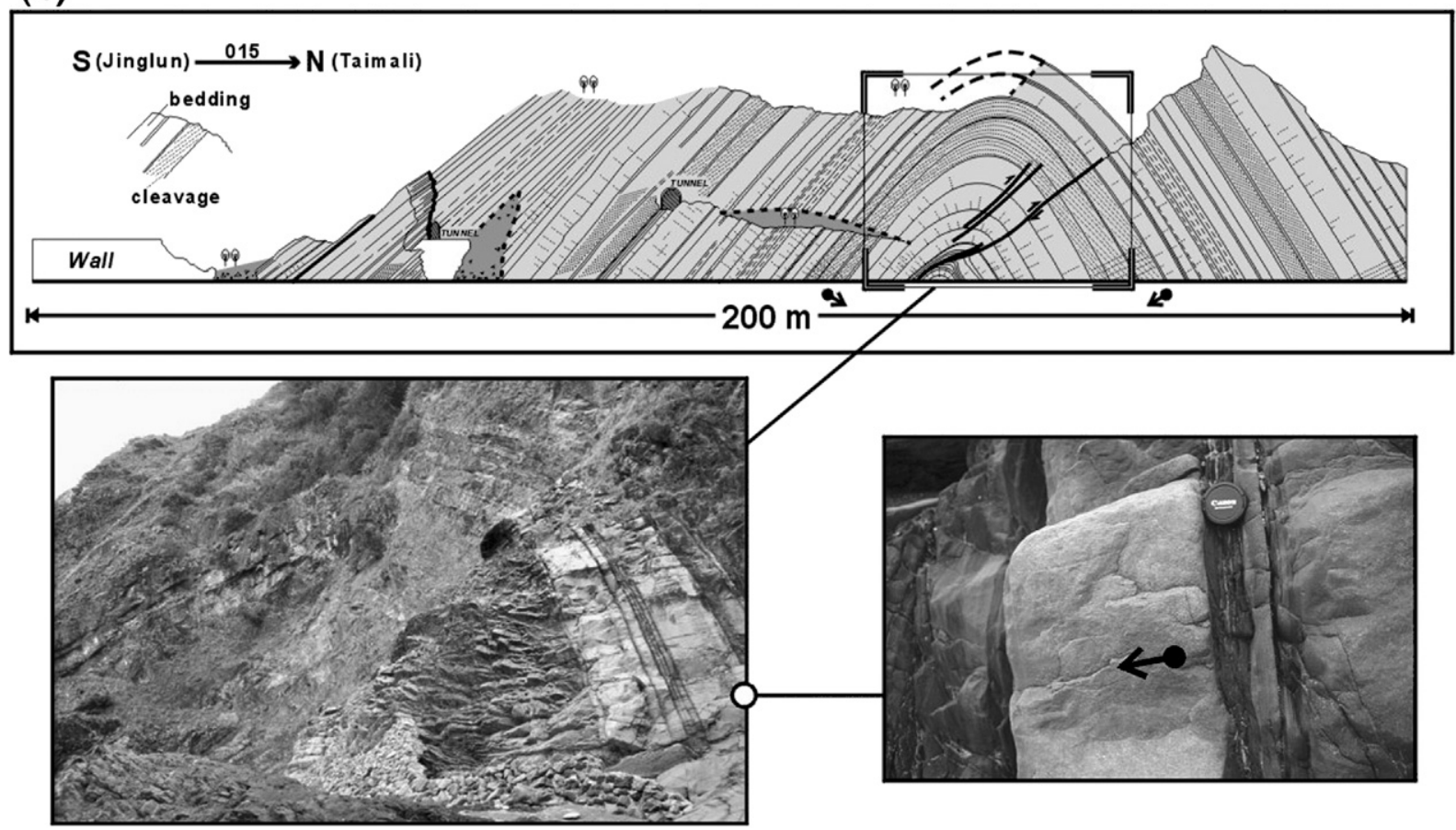

Fig. 8. East-west striking Antiforms in the Lushan Formation of the Taimali beach. Many sedimentary structures (including: graded bedding, flute cast, cross bedding, loading structure, etc.) indicate that the strata were overturned before this folding.

concerning the regime responsible for $\Psi 3$ in terms of direction, age and depth, we collected the specific tectonic data sets discussed below.

\section{Tectonic data analysis}

Although the structural superposition is widespread in the eastern flank of the southern Central Range, the strike of measured bedding surfaces in this area still shows a concentrated distribution with an average orientation of about NNWSSE (Fig. 9a, data of the Taimali beach not included). This distribution is controlled by a WSW-ENE compression, that is, the average tectonic regime of $\Psi 1$ and $\Psi 2$. This direction of compression can also be observed by analysing the slaty cleavage and stretching lineation. In Fig. 9b, all the measured cleavages of $\Psi 1$ and $\Psi 2$ are shown; despite dispersion the direction of WSW-ENE is clearly expressed and also reflect the compression in this direction. The stretching lineation in company with this deformation stage is generally SE-NW oriented, with an elongation of about $150 \% \sim 300 \%$ subparallel to fold axes of $\Psi 2$ along the coastal area.

After considering the structural relationships between successive cleavages, a new group of cleavages (joint-like spaced cleavage) could be distinguished along the coastal area, as related to $\Psi 3$. Most planes of cleavage $\Psi 3$ shown in Fig. 9c are nearly vertical; however, their orientations show large azimuthal dispersion. This dispersion may result from three causes: (1) $\Psi 3$ had a complex tectonic history, during this last stage the direction of stress changed with time; (2) $\Psi 3 \mathrm{had}$ a complex tectonic regime, with compressive stress acting in different directions simultaneously; (3) horizontal block rotations occurred during $\Psi 3$, resulting in apparent stress rotations although the direction of compression was constant. These causes are not mutually exclusive. To check these aspects, we carried out a paleostress analysis.

To determine the paleostress distribution and its evolution, we have analysed the brittle deformation in the southern Central Range. More than 29 sites have been studied in detail. The 

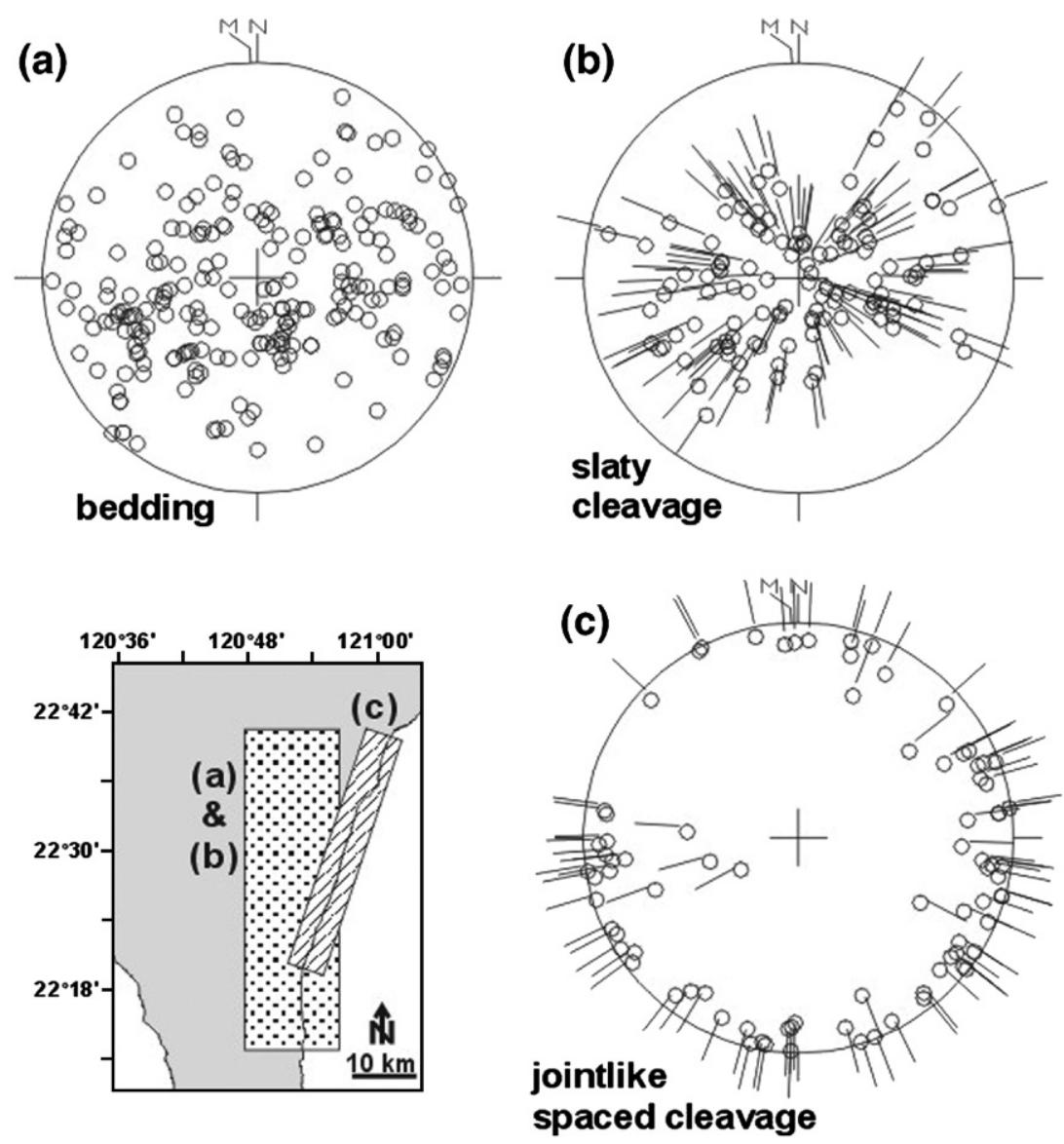

Fig. 9. Summary of orientations of stratigraphic bedding and cleavage recorded in the eastern flank of the southern Central Range. Poles to bedding on cleavage shown in lower hemisphere, equal area projection stereoplots. (a) stratigraphic bedding, $\Psi 0$; (b) slaty cleavages of $\Psi 1$ and $\Psi 2$; (c) joint-like spaced cleavages of $\Psi 3$. The measurement area of these data is shown in lower left, data of the Taimali beach not included, see Fig. 7.

measured faults are analysed by computer means, using inverse methods described and discussed in previous papers (Angelier, 1989, 1990). Particular attention was paid to the geometrical relation of fault-fracture systems to bedding attitudes and fold shapes. This was because the geometrical analysis allowed distinction between pre-folding, syn-folding and post-folding brittle tectonic events. By considering the attitudes of the computed principal stress axes relative to the bedding planes at sites where significant tilting has occurred (especially for stratal dips steeper than about $30^{\circ}$ ), it was possible to distinguish the faulting events that predated or postdated folding. In postfolding faulting, one axis is usually found nearly vertical $\left(\sigma_{1}, \sigma_{2}\right.$ or $\sigma_{3}$, depending on whether normal, strike-slip or reverse faulting mode dominated). In contrast, where pre-folding faulting has occurred, this axis is not vertical, but approximately perpendicular to tilted bedding.

Based on differences in the types and orientations of the tectonic regimes, we thus distinguished three main periods of faulting in the southern Central Range. To summarise, the first tectonic regime indicated by fault analyses (Fig. 10a) is normal in type, with a $\sigma_{3}$ axis trending NW-SE to E-W (ESE-WNW on average). The second regime is mainly reverse in type, with a $\sigma_{1}$ axis trending $\mathrm{E}-\mathrm{W}$ on average; however, the distribution of $\sigma_{1}$ trends is clearly bimodal for this brittle regime, with peaks in the WSW-ENE and WNW-ESE directions (Fig. 10b). For the third regime, the directions of the $\sigma_{1}$ and $\sigma_{3}$ axes are approximately NNW-SSE and ENE-WSW, respectively (Fig. 10c), but with large dispersion of $\sigma_{3}$ trends. However, the dispersion diminishes if the data from the most recent faults are selected for this last regime, which suggests that the complete data set includes some data from other brittle regimes.

During the first stage (Fig. 10a), normal faults accommodated synsedimentary WNW-ESE extension during the MidLate Miocene time, in good agreement with regional geology (Lin and Watts, 2002). Large deformation had not yet occurred; the brittle regime can thus be considered as the stress of $\Psi 0$. After this stage, as a result of the continuing propagation of the Taiwan accretionary prism toward the northwest, the sediments of the continental margin (the future Central Range) were incorporated into the accretionary prism and affected by thrust faults.

The E-W compression deeply affected the structure of our study area during the second stage (Fig. 10b). In more detail, the stress of this stage includes two groups of $\sigma_{1}$ trends: the earliest group trends approximately E-W or WSW-ENE, whereas the next group trends WNW-ESE. A comparison with the tectonic events mentioned before suggests that these azimuthal groups may be related to the thrusting stage $(\Psi 1)$, with WSW-ENE $\sigma_{1}$ 
(a) 1st stage (extension)

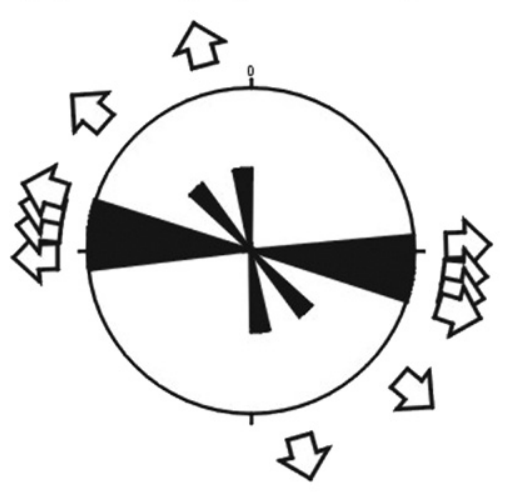

(b) 2nd stage (compression)

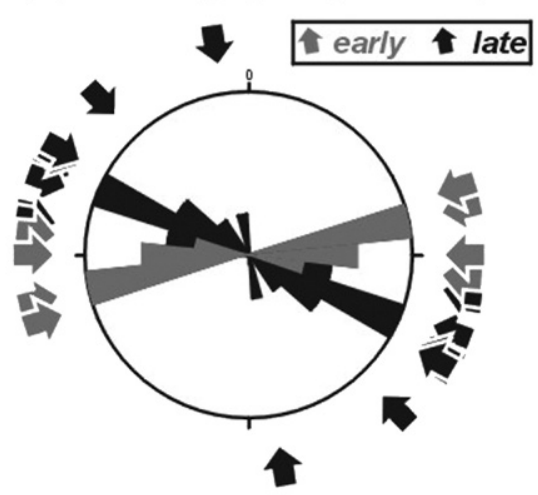

(c) 3rd stage (transpression)

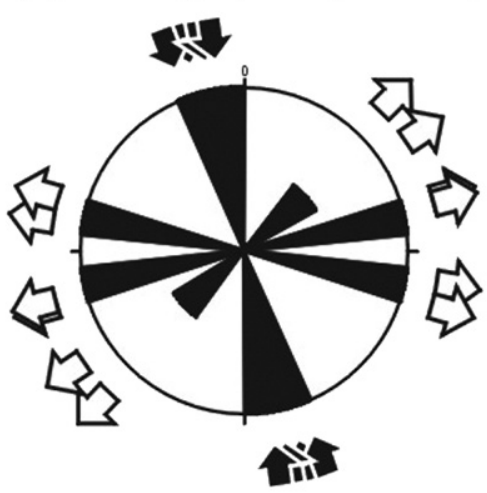

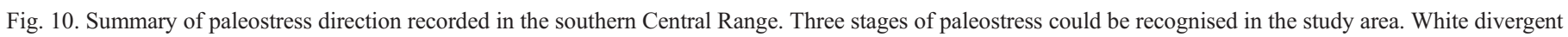

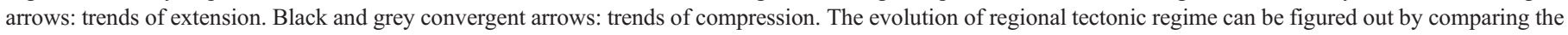
paleostress record with the stratigraphic and cleavage data.

trends, and backthrusting stage $(\Psi 2)$, with WNW-ESE $\sigma_{1}$ trends. This clockwise change of about $35^{\circ}$ in the direction of compression is discussed in the next section.

Concerning the last major paleostress regime, a new change in the direction of compression is evidenced, averaging $55^{\circ}$ clockwise. In addition, this last regime is predominantly strikeslip in type, with NW-SE transpression and NE-SW transtension (Fig. 10c). The cleavage dispersion of event $\Psi 3$ does not necessarily indicate a complex tectonic history. Because these possible regimes of $\Psi 3$ have only been found in the eastern flank of the southern Central Range, where near the recent collision suture zone (the Longitudinal Valley and its southern extension), these regimes may be caused by the oblique compression from the northwestward-converging neighbouring Luzon volcanic (Fig. 10). The change from $\Psi 2$ to $\Psi 3$ may reflect the increasing collision in the southern Central Range, resulting in a component of left-lateral displacement along the eastern flank of the range. It may also result from a bending of the belt, as discussed in the next section.

\section{Discussion and conclusion}

Because they bring strong structural constrains, our results about the tectonic evolution of the southern Central Range suggest a new perspective for the deformation of an accretionary prism when oblique arc-continent collision occurs. We discuss the structural evolution of our study area in terms of four main stages (Fig. 11).

The stage $0(\Psi 0)$ corresponds to the Early to Middle Miocene time in southern Taiwan. The South China Sea oceanic crust was subducting beneath the Philippine Sea plate along the Manila trench, far away to the east from the future southern Central Range domain (Fig. 11, Stage 0). The terrigenous sediments of this domain were supplied from the Chinese continent from northwest. Series of normal faults were produced by synsedimentary WNW-ESE extension at this stage (the first stage of the paleostress record in Fig. 10a).

The stage I $(\Psi 1)$ corresponds to the Late Miocene to Pliocene time in southern Taiwan. The accretionary prism was gradually approaching the future southern Central Range domain; the sediments of this domain began to be submitted to compression. The Miocene sediments of the Central Range were then incorporated into the accretionary prism by thrust faults (trench or thrust front) (Fig. 11, Stage I). The E-W compression prevailed as a mainly reverse-type tectonic regime (early second stage of paleostress record, gray trends in Fig. 10b).

The stage II $(\Psi 2)$ corresponds to the Pliocene time in southern Taiwan. The continuing compression between the volcanic arc and the continental margin (with almost the same direction as for stage I) had induced series of east-verging backthrust within the eastern flank of Central Range. The strata of the easternmost area have therefore been overturned (Fig. 7). The oblique convergence setting has recently been studied in various ways (e.g., Chemenda et al., 2000; Martinez et al., 2002), suggesting that partition of deformation through time occurs and may result in superimposed deformation structures and progressive rotations as deformation increases. Because of the oblique geometry of the convergence propagation, the continuing compression between the volcanic arc and the continental margin might result in a limited counterclockwise rotation of the Miocene formations in the study area (Fig. 11, Stage III). The previous paleostress record (that of $\Psi 1$ ) was of course affected by this physical rotation. An apparent change in stress direction effectively occurred between the early and late second stage in Fig. 10b, about $35^{\circ}$ clockwise). This apparent clockwise change with time is consistent with the hypothesis of a counterclockwise physical rotation under a relatively stable orientation of regional stress.

During the Plio-Pleistocene time, arc-continent collision occurred in Taiwan, as stage III in our study area. According to a previous study of the tectonic evolution at the southern tip of the Taiwan mountain range (Chang et al., 2003), the Hengchun Peninsula has undergone significant anticlockwise rotation. This was probably because the Hengchun Peninsula (Hengchun block) was totally detached by large faults from its basement (root) and became a "free" block in the collision belt. However, in the southern Central Range, no evidence supports such an interpretation, because the pre-developed western verging thrust and eastern verging backthrust are apparently not large enough 

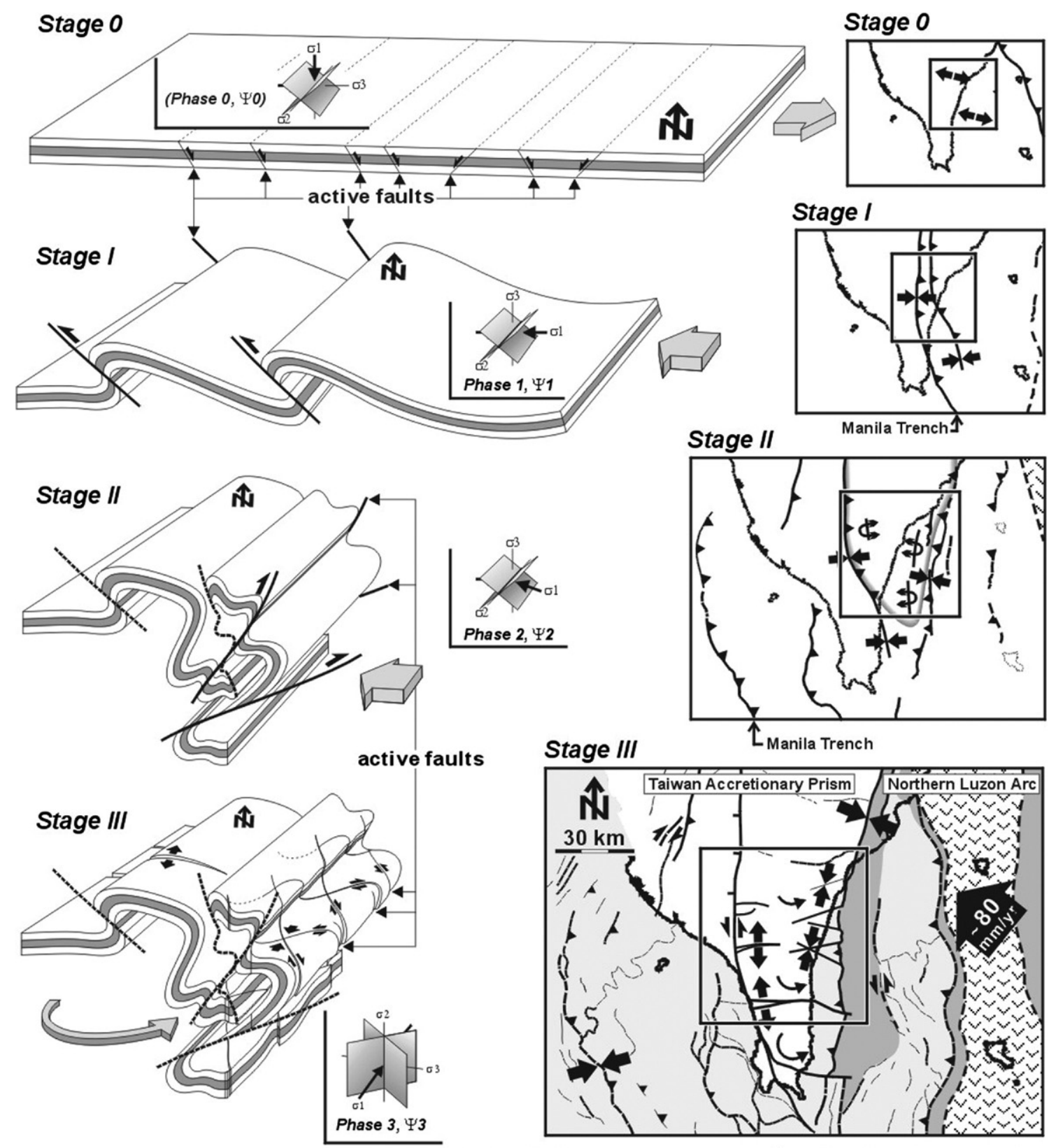

$\checkmark$ thrust $\$$ isoclinal anticline

Fig. 11. Summary of the tectonic evolution of the southern Central Range. Note the apparent change in compression direction during the Stage III, as a consequence of the rotation of the mountain block. More explanation in text.

to detach the upper mountain and its basement. Therefore, the rotation occurring in this area should have affected the ductile deformation in the lower observed formations. Because the ductile deformation occurred deeper than the thrust detachment, it could accommodate only limited horizontal movement. Despite these limitations, and considering the regional geometry of major structures, this movement could induce a "spine-likeeffect" in the southern Central Range and produce conspicuous compressional structures in a limited area (stage III in Fig. 11, see also Fig. 12).

It is worth noting that although the axis of the Taiwan mountain range trends NNE-SSW just north of our study area, it gradually becomes $\mathrm{N}-\mathrm{S}$ to the south of our study area
(Fig. 12). This anticlockwise rotation from $\mathrm{N}$ to $\mathrm{S}$, which clearly expressed in the morphology and structure, may have been produced by the difference in the degree of collision. In simple words, to the north the collision is intense (mature collision stage), whereas to the south the collision is still immature (incipient collision stage). Because of this difference in collision stage (and hence rotation), the mountain range was segmented into blocks. Between the blocks with different amount of rotation, and similar to the joints of a curved spine (Fig. 12), one side undergoes extension (in this case the western side) and the other side undergoes contraction (in this case the eastern side). Because our study area is located at the change point of the mountain trend, this "spine-like-effect" is expected to induce 


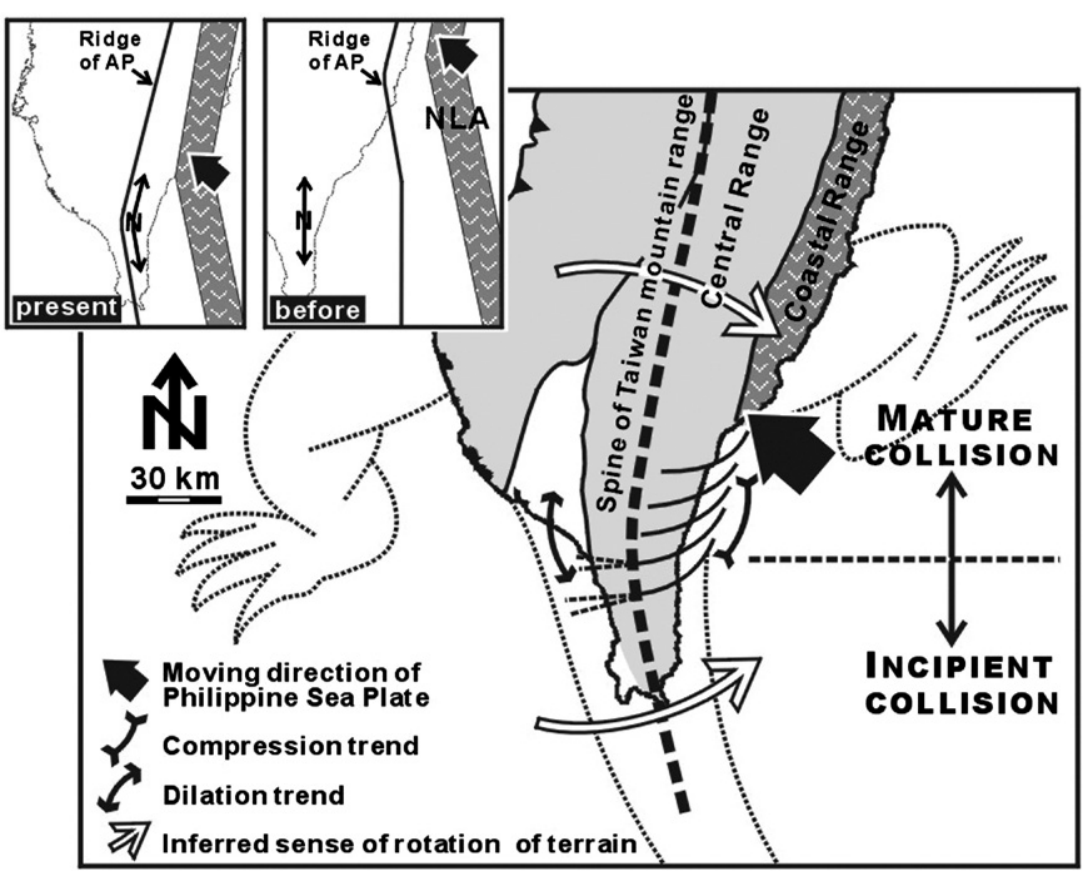

Fig. 12. Interpretative model of the recent deformation in the southern Central Range of Taiwan. To this respect, the Taiwan mountain range resembles the spine of a large reptile. When the reptile creeps, one side of its body contracts and the other one side expands. This analogy allows to explain why, during the last major tectonic event, E-W trending folds (i.e., N-S contraction) occur in the eastern flank of the southern Central Range, whereas in the western flank extensional structures probably develop. On upper left: Geometry of Northern Luzon arc (NLA) and ridge of Taiwan accretionary prism (AP), before and after the mature collision. N with arrow shows the north direction recorded in primary structures.

extension in western flank and compression in the eastern one (Fig. 12). This simple model of "spine-like-bending" well accounts for our tectonic observations, especially the $\mathrm{N}-\mathrm{S}$ compression (Stage III, $\Psi 3$ ) that affects the east flank of the southern Central Range.

Because of this rotation and the oblique convergence of the volcanic arc, the eastern flank of Central Range was submitted to the tectonic regime of a combination of $\mathrm{N}-\mathrm{S}$ transpression and $\mathrm{E}-\mathrm{W}$ transtension (third stage of paleostress record in Fig. 10). This interpretation also accounts for the local development of E-W trending structures such as the major folds described in Figs. 7 and 8, and for the azimuthal dispersion of the cleavage of $\Psi 3$, as shown in Fig. 9c. We could not characterize clear extensional structures on the western flank of the southern Central Range, as could be expected (Fig. 11, Stage III, and Fig. 12). However, some observations along the E-W running valleys near Fongkang and Fangshan (Location in Fig. 2) suggest that they could be the sites of extensional structure compatible with $\mathrm{N}-\mathrm{S}$ extension. Furthermore, such an extension would be compatible with, and facilitated by, the extensional "escape" phenomenon in southwestern Taiwan (Angelier 2007this issue).

Although many previous studies revealed that the deformation of the Taiwan orogen usually involves both tilting and rotation (Lee et al., 1990, 1991; Lu and Malavieille, 1994; Chang et al., 2003), the existence of tectonic rotation remains problematic in the Central Range in Taiwan, where large uplift and erosion have occurred. Paleomagnetic studies in the southern Central Range met technical difficulties, mainly related to the nature of magnetic minerals (work with Dr. T.-Q. Lee, unpubl. data).

In this study, we identified three stages of paleostress according to brittle tectonic analysis in the southern Central Range. After combining this result with the field observation, we reconstruct the tectonic evolution of the southern Central Range from the Early Miocene (the extension stage) to the PlioPleistocene collision stage. In this reconstructed model, thrusting deformation, backthrusting deformation and a tectonic rotation have been considered. It is worthwhile to point out that the tectonic rotation is a probably repeatable phenomenon, not an accidental one. It occurs in the oblique collision system when the mountain range moves from the incipient collision stage into the mature collision, a situation that repeatedly took place in the past, moving from north to south along the Taiwan belt. Evidences of older deformation events of this type in the eastern Central Range north of our study area however remain to be found.

\section{Acknowledgements}

This work was supported by the National Science Council (NSC grant no. 95-2119-M-008-034), the Central Geological Survey (CGS grant no. 5226902000-02-95-04) of Taiwan and the France-Taiwan co-operation frame supported by the IFT (French Institute in Taipei) and NSC. Helpful suggestions and reviews by Dr. Hao-Tsu Chu and editor greatly improved the manuscript. Extensive discussion with Drs. Y.C. Chan, T.Y. Chang, A.T. Lin, J. Malavieille, J.Y. Yen have been very helpful. 


\section{References}

Angelier, J., 1989. From orientation to magnitudes in paleostress determinations using fault slip data. J. Struct. Geol. 11, 37-50.

Angelier, J., 1990. Inversion of field data in fault tectonics to obtain the regional stress. III. A new rapid direct inversion method by analytical means. Geophys. J. Int. 103, 363-376.

Angelier, J., Chang, T.Y., Hu, J.C., Chang, C.P., Siame, L., Lee, J.C., Deffontaines, B., Chu, H.T., Lu, C.Y., 2007. Does extrusion occur at both tips of the Taiwan collision belt? Insights from active deformation studies in the Ilan Plain and Pingtung Plain regions. Tectonophysics. doi:10.1016/j. tecto.2007.11.015.

Biq, C., 1973. Kinematic pattern of Taiwan as an example of actual continentarc collision. Report of the Seminar on Seismology. US-ROC Cooperative Science Program, 25, 149-166.

Bowin, C., Lu, R.S., Lee, C.S., Schouten, H., 1978. Plate convergence and accretion in Taiwan-Luzon region. Am. Assoc. Petr. Geol. Bull. 62, $1643-1672$

Chai, B.H.T., 1972. Structure and tectonic evolution of Taiwan. Am. J. Sci. 272, 389-422.

Chang, C.P., Angelier, J., Lee, T.Q., Huang, C.Y., 2003. From continental margin extension to collision orogen: structural development and tectonic rotation of the Hengchun peninsula, southern Taiwan. Tectonophysics 361, 61-82.

Chemenda, A., Lallemand, S., Bokun, A., 2000. Strain partitioning and interpolate frictin in oblique subduction zones: constraints provided by experimental modelling. J. Geophys. Res. 105 (B3), 5567-5581.

Chen, C.H., Chu, H.T., Liou, J.G., Ernst, W.G., 1983. Explanatory notes for the metamorphic facies map of Taiwan. Spec. Publ. Cent. Geol. Surv. 2, 1-3.

Fisher, D.M., Lu, C.Y., Chu, H.T., 2002. The Taiwan slate belt: insights into the ductile interior of an arc-continent collision. GSA Special Paper 358, 93-106.

Ho, C.S., 1986. A synthesis of the geologic evolution of Taiwan. Tectonophysics $125,1-16$.

Hu, H.N., Tsan, S.F., 1984. Structural study of the slate formation along the South Link Railroad, Taiwan. Spec. Publ. Cent. Geol. Surv. 3, 25-43.
Hu, H.N., Chu, H.T., Jeng, R.C., 1981. The slate formation of southern Taiwan: preliminary result. Bull. Cent. Geol. Surv. 1, 33-49.

Lee, T.Q., Angelier, J., Chu, H.C., Bergerat, F., 1991. Rotation in the northeastern collision belt of Taiwan: preliminary results from paleomegnetism. Tectoniphysics 199, 109-120.

Lee, T.Q., Kissel, C., Horng, C.S., Lue, Y.T., 1990. Magnetic fabric analysis of the Plio-Pleistocene sedimentary formations of the Coastal Range of Taiwan. Earth Planet. Sci. Lett. 98, 23-32.

Lin, A.T., Watts, A.B., 2002. Origin of the western Taiwan basin in orogenic loading and flexure of a rifted continental margin. J. Geophys. Res. 107 (B9), 2185. doi:10.1029/2001JB000669.

Lu, C.Y., Malavieille, J., 1994. Oblique convergence, indentation and rotation tectonics in the Taiwan Mountain belt: insight from experimental modelling. Earth Planet. Sci. Lett. 121, 477-494.

Lu, C.Y., Chang, K.J., Malavieille, J., Chan, Y.C., Chang, C.P., Lee, J.C., 2001. Structural evolution of the southeastern Central Range, Taiwan. West. Pac. Earth Sci. 1, 213-226.

Martinez, A., Malavieille, J., Lallemand, S., Collot, J.Y., 2002. Strain partitioning in an sccretionary wedge, in oblique convergence: analogue modeling. Bull. Soc. Geol. France 173 (1), 17-24.

Page, B.M., Lan, C.Y., 1983. The Kenting Mélange and its record of tectonic events. Mem. Geol. Soc. China 5, 227-248.

Pelletier, B., Hu, H.N., 1984. New structural data along two transects across the southern half of the Central Range of Taiwan. Mem. Geol. Soc. China 6, $1-19$.

Pelletier, B., Stephan, J.F., 1986. Middle Miocene obduction and late Miocene Beginning of collision registered in the Hengchun peninsula: geodynamic implications for the evolution of Taiwan. Mem. Geol. Soc. China 7, 301-324.

Sung, Q., 1991. Geological Map and the explanatory text for the Hengchun peninsula, south Taiwan, on scale 1:50000. Central Geological Survey, MOEA, Taiwan.

Suppe, J., 1984. Kinematics of arc-continent collision, flipping of subduction and back-arc spreading near Taiwan. Mem. Geol. Soc. China 6, 21-34.

Tsai, Y.B., 1986. Seismotectonics of Taiwan. Tectonophysics 125, 17-37.

Yu, S.B., Chen, H.Y., Kuo, L.C., 1997. Velocity field of GPS stations in the Taiwan area. Tectonophysics 274, 41-59. 